\title{
Determinants of SME exporting
}

\section{Insights and implications}

\section{David Pickernell, Paul Jones, Piers Thompson and Gary Packham}

\begin{abstract}
This study offers insights into determinants of SME exporting according to the characteristics of exporting firms and their resources, thus contributing to a limited literature. The dataset comprised 4,838 respondents from a survey of the UK Federation of Small Businesses. The dependent variable used was two-category ('do not export' and 'export'), allowing a binary logistic multiple regression approach to be used, with separate binomial (logit) regression equations generated for the complete sample and then for different firm age groupings, allowing relationships between exporting and each individual independent variable to be determined whilst holding all other independent variables in the equation constant. The results show that determinants of SME exporting include industry sector, age and the characteristics of the SME owner-manager, along with the firms' available resources, including the human capital of the owner-manager, use of technology and intellectual property. While an innovation focus was consistently found to be positively linked to exporting, a growth focus was not. These results inform both practice and policy, as the exporting activity of SMEs remains closely linked to economic development policy.
\end{abstract}

Keywords: innovation; exporting; SME

David Pickernell is Professor of Economic Development Policy, University of South Wales, Pontypridd, Cardiff, UK. E-mail: david.pickernell@southwales.ac.uk. Paul Jones (corresponding author) is Deputy Director of the International Centre for Transformational Entrepreneurship and Professor of Entrepreneurship at Coventry University, Priory Street, Coventry CV1 5FB, UK.

E-mail: ac0359@ coventry.ac.uk. Piers Thompson is Reader in Entrepreneurship and Small Business Management at Nottingham Trent University, Nottingham, UK. E-mail: piers.thompson @ ntu.ac.uk. Gary Packham is Professor of Entrepreneurship at Anglia Ruskin University, Cambridge, UK. E-mail: gary.packham@anglia.ac.uk.

Small and medium-sized enterprises (SMEs) have a high dependency on local markets, with minimal trade undertaken in national or global markets (Love et al, 2005). 'Born-global' firms, however, are also attracting increasing interest (Oviatt and McDougall, 1994). Knight et al (2004) contend that 'born-global' firms have given rise to international entrepreneurship, raising the issue of the differences between young international firms compared with both young firms that are not international and older internationalized firms.
Traditionally, we consider SMEs' internationalization from three theoretical approaches (Bell and Young, 1998). First, there is the stages of development approach, in which firms incrementally become involved in foreign markets, from no regular exporting, through exporting via agents and sales subsidiaries to similar countries, to foreign production and manufacturing (Clark and Pugh, 2001). Second, there is network theory, in which exporting occurs as a result of interactions with and the development of networks through 
which information and trust are generated (Chetty and Blankenburg Holm, 2000). Lastly, there are resourcebased approaches, in which internationalization decisions occur in the context of the development of internal/external resources and environments as part of a strategy (Crick and Spence, 2005).

The literature recognizes that some firms 'leapfrog' stages of internationalization, while others remain static (Merrilees and Tiessen, 1999). SMEs may enter international markets through equity participation or cooperative ventures (Pinho, 2007). Merrilees and Tiessen (1999) also note, however, that SMEs first enter international markets through exporting, while Pinho (2007) claims that they have restricted their internationalization behaviour to exporting alone.

Patterns of SMEs' exporting behaviour are not consistent. The Global Entrepreneurship Monitor study found that $80 \%$ of new firms had no exports, with particular weaknesses in start-ups. Arteaga-Ortiz and FernándezOrtiz (2010) identified a limited literature exploring SMEs' exporting behaviour, which included evaluating the impact of export barriers, firm performance (Di Chiara and Minguzzi, 2002), internal capabilities, exporting activity, SMEs' capacities (Miocevic and CrnjakKaranovic, 2011) and firm resources (Boehe, 2013).

This study examines how exporting SMEs of different ages differ from non-exporters in terms of their characteristics and resources. For example, regarding the relationship between exporting and growth, there is the concept that businesses start small, with a focus on growth that is then achieved through capitalizing on the opportunities offered by entering overseas markets. The literature on business growth through internationalization has focused on new SMEs, which, in keeping with the European definition, have fewer than 250 employees, a turnover of up to 50 million euros and a balance sheet of up to 43 million euros (Jones et al, 2014). By focusing on the exporting stage of SME activity, this study identifies export characteristics compared with non-exporters, including a consideration of firm-level determinants identified in the literature as sector, size, growth focus and age. Owner-manager-specific characteristics are considered, including age, experience and firm resources such as information and communications technology (ICT), intellectual property (IP) and human capital (HC). Understanding this perspective determines whether a firm will export more effectively than more generalized stage models that are less relevant to SMEs, in which exporting remains the primary mode of internationalization.

\section{Literature review}

Axinn and Matthyssens (2002) suggest three reasons why traditional theories of internationalization have limited relevance. First, traditional theoretical approaches may not fit current economic realities and underlying assumptions regarding the rapidity with which relationships in the international marketplace form and evolve. Second, the concept of psychic distance associated with internationalization process models is of less relevance when considering the growth of global e-commerce in an increasingly culturally homogeneous world. Finally, stage models have limited relevance to firms involved in different kinds of cooperative agreements that have evolved in the network economy. The authors recognize that the phenomenon of the 'bornglobal' firm represents a challenge to traditional theories of SME firm internationalization (Knight et al, 2004). Moreover, traditional theoretical frameworks of firm internationalization only explain how internationalization occurs, rather than why. There is a need to utilize the factors contained in these frameworks to examine why the process occurs. Two issues the literature focuses on are why SMEs internationalize and export, and the potential impact of firm age on these processes.

\section{Why do SMEs internationalize?}

Research suggests that several factors influence SME internationalization, depending on industry (external environmental) and internal firm-specific factors (Gassmann and Keupp, 2007). Ibeh (2000) suggests that the decision depends on the characteristics of the decision maker, firm characteristics, competencies and environment. Moen (2002) found that the decision maker's attitude was a determinant of whether a new firm would be born-global or local, and suggested that its future was determined at establishment. The firm's owner-manager's attitude and human resources have been cited as significant differentiators between exporting and non-exporting SMEs (Frackiewicz and Grzesiuk, 2013). Hessels and Terjesen (2008) argue that higher levels of entrepreneurial $\mathrm{HC}$ are positively related to exporting by new venture companies. Such entrepreneurial HC refers to an individual's knowledge and skills, as well as to experience gained in entrepreneurial activity.

One measure of HC may be education. Pickernell et al (2011) found that graduate entrepreneurs exported a higher proportion of their turnover than non-graduateowned firms, and that graduate entrepreneurs were likely to have had prior experience in a multinational, though less likely to have previously owned or managed a business. Attributes associated with exporters include enhanced decision-making skills, leading to higher levels of competitiveness, growth and profitability than non-exporters. Such attributes are assumed to be linked with 'best practice' and entrepreneurial orientation (Kazem and Van der Heijden, 2006).

Miocevic and Crnjak-Karanovic (2011) suggest that 
key specific capabilities required by SME ownermanagers include possessing a 'global mindset' consisting of cognitive and information-based skills and an international entrepreneurial orientation. Camisón and Villar-López (2010) note previous international experience as giving no guarantee of success, claiming that it is the accumulation of human and social capital (SC), intangible assets and strategies formed by previous international experience that positively impact on export performance.

Kontinen and Ojala (2010) stated that previous experience was not the sole indicator of successful export performance, but rather how it was operationalized. They found no direct link between prior firm knowledge and an ability to recognize international opportunities. Mittelstaedt et al (2003) found a significant positive relationship between firm size (by employment) amongst SMEs and successful exporting (Chetty and Campbell-Hunt, 2004). Pope (2002) identified similarities in motivations for exporting activity depending on firm size in that both smaller $(<$ 25 employees) and larger ( $>25$ ) firms were more likely to export due to a new product or technological advantage. Furthermore, Pope noted a difference in motivations to export, along with firm size, as larger firms export on a large scale, seeking cost advantages and not wanting to sacrifice opportunities, emphasizing the difference in perceived risk and potential gain between smaller and larger firms. Arteaga-Ortiz and Fernández-Ortiz (2010) proposed a scale of barriers across themes of knowledge, resource, procedural and exogenous barriers employed to assess and effectively support SMEs. They suggested that firms displayed different requirements to enable them to overcome factors that inhibited export activity.

Several barriers to exporting need to be overcome, mirroring the triggers highlighted previously. Smarzynska Javorcik (2004) posits that when a firm trades in foreign markets, it is initially disadvantaged relative to local producers. Kaleka and Katsikeas (1995) summarize these disadvantages as:

- Internal-firm domestic impediments: lack of qualified marketing personnel, high export risk perception, focus on home market.

- Internal-firm foreign impediments: lack of marketing capability where product modification investment is required in after-sales issues, pricing, communication and transportation costs.

- External foreign-market impediments: created by foreign government regulations and currency issues, the need to develop external networks, distributors, language/cultural differences, foreign competition, price competitiveness and payment issues.
Leonidou (2004) identifies internal/external barriers at different stages of export activity and at pivotal moments between stages. Massey (2006) also highlights the 'interrelation' between the firm and the owner-manager, especially considering business development support, suggesting that services should support their development, whilst Bell (1997) found that finance-related issues tended to increase as foreign market exposure grew, but that marketing (information and network development) declined over time. Andersson et al (2004) argued that factors influencing initial exporting differed from those influencing its growth. Ownermanagers' perceptions of the environment determine initial exporting, whilst longer-term organizational experience of exporting and more youthful decision makers encourage growth.

Comparing the decision maker, firm characteristics and environment, Fliess and Busquets (2006) stated that SMEs considered lack of internal capabilities and access as being significant barriers to internationalization, whilst business environment inhibitors were of lesser importance. Greenaway et al (2007) found that financially constrained firms were less likely to export, and that financially stable firms were more sensitive to export investment.

Hessels and Terjesen (2008) suggest that there is a positive relationship between entrepreneurial SC (advice/knowledge regarding new markets) and exporting. Regarding access to business advice, Mole et al (2008) note that the characteristics of the firm have an influence on the adoption and impact of formal business advice. Mole et al's study identifies that younger firms are more likely to receive support, although growth was not a significant impact acknowledged by businesses receiving support. It is suggested that formal business advice would have a greater impact on larger, exportoriented businesses.

Conversely, Robson and Bennett (2000) acknowledge a weak association between access to formal business advice sources and the impact on export levels, but also recognize a likelihood of the use of informal advice sources such as friends/relatives and customers. Potentially, this link to customers indicates a preference for a direct, rapid link to market trends and customer needs from trusted sources to the firm.

Boehe (2013) identifies a positive relationship between local domestic collaborations and exporting, suggesting that collaborations such as membership of industry associations and local firms assist in overcoming barriers to internationalization, and that industry association memberships in particular influence the propensity to export. In social network theory, Boehe's (2013) findings suggest that firm collaboration and investment in SC address the perceived lack of internal 
resource or knowledge capabilities, thus encouraging entry into export activity.

Considering the relationship between exporting, firm performance and related factors, Wright et al (2007) suggest that the link between exporting and firm performance is inconsistent in how to measure benefit, and that geographical, cultural and industry contexts should be considered. Westhead et al (2004) did not identify a statistically significant relationship between exporting and superior firm performance (compared with nonexporters), which indicates the importance of determining factors that improve successful exporting activity.

Crick and Chaudhry (2006) query the assumption that not exporting or deciding to discontinue is a sign of export strategy failure. They argue that export inactivity may follow an iterative pattern with short-term and long-term epochs of non-exporting activity, rather than stage models and viewing lack of exporting as failure. They conclude that strategic decisions around competitiveness far outweigh issues such as 'psychic distance' mentioned in certain models when considering whether or not to export.

Hart and Tzokas (1999) found a positive relationship between gathering market data and successful exporting, with specific importance attached to information on market background and infrastructure, as well as proactive, formal market data gathering and use of the data in strategy generation. Holzmuller and Stottinger (1996) identified that less centralized firms with more flexibly organized, goal-driven and consensus-based decision making had more effective export performance, indicating a need to promote such structures. Moreover, Di Chiara and Minguzzi (2002) claimed that specialized skills and scaled dis-economies inherent in SMEs presented an internationalization barrier, which must be overcome through promoting the provision of customized services.

Abor and Biekpe (2006) noted that SME exporters had difficulties accessing loans due to high interest rates and collateral requirements, and this limited export growth in terms of future production and marketing capabilities. Beck and Demirguc-Kunt (2006) also suggested that financial and institutional development assistance alleviated SMEs' growth constraints and increased access to external finance, enabling competition with larger firms. Gabrielsson et al (2014) identified positive links between growth and finance sources, suggesting that growing firms that accessed finance, especially those with high levels of internationalization, tended to sustain a growth trajectory.

However, Abor and Biekpe (2006) did not identify any association between access to finance and export intensity.

Moen (2002) argued that growth level and commit- ment implied by the stage model approach to exporting was less valid for SMEs, as they typically did not develop into large companies. Such approaches are less applicable to SMEs in certain high-technology sectors with short life-cycles and the need to exploit large markets (Madsen and Servais, 1997) in which the greater use of networks from an earlier stage to overcome resource constraints (Pellinen, 2014) and in which 'first mover status' was of greater value (Crick and Chaudhry, 2006).

Maskus and Penubarti (1995) found that IP protection had a positive impact on manufacturing imports for developing economies, and Smith (2001) noted that IP was a significant determinant of economic growth. In contrast, Primo Braga and Fink (2000) found no significant relationship between firm export capability and levels of IP protection.

\section{Firm age and exporting}

The impact of firm age on exporting is one potentially linked to firm and owner-manager characteristics, resources and environment, thus requiring specific analysis. Barnes et al (2006) considered the organizational culture and the owner-manager's firm confidence to be associated with the success of 'born-global' companies.

Fletcher (2004) noted a difference between SMEs that were 'born-global' in industries and sectors where internationalization was a consequence of conditions in globalized markets and those that internationalized following a period of home-market focus. In the former, internationalization utilizes the existing skills base required to initiate the business, and issues involve the development of existing skills, knowledge and networks, whereas later internationalization requires the extension and expansion of existing skills and the development of resources through network development. The growing importance of the Internet is lowering barriers to internationalization (Hamill and Gregory, 1997) in terms of information gathering, marketing and networking. Indeed, Internet growth appears to be making stage-based approaches less relevant for SMEs.

The Internet and social media options also offer the type of globally expansive, rapidly formed networks that Chetty and Campbell-Hunt (2004) attributed to bornglobal firms, as opposed to more slowly internationalizing firms. Au and Ho (2002) saw the growth of e-commerce as making it imperative for government export policy to be aligned with the need to train and support SME usage of new technologies. Frackiewicz and Grzesiuk (2013) questioned the true internationalization of the Internet in terms of changing customer attitudes. 
Importantly, Hinson and Abor (2005) confirmed a link between firm age and Internet usage (older firms used the Internet less frequently), but found no association between Internet use and export performance. Balabanis et al (2004) identified that the Internet had contributed to the removal of SMEs' export barriers. They stressed that such opportunities could be exploited only by firms with the necessary export infrastructure, possessing the required knowledge, skills and resources to expand internationally. This leads us to identify ICT usage as of potential but not ultimate importance in exporting.

Unsurprisingly, the born-global phenomenon is recognized in technology-oriented industries (Crick, 2009). This highlights the potential for innovation to be of relevance in any analysis of exporting. Kocak and Abimbola (2009) found firms were deemed to be innovative and sought to gain enhanced competitive performance from the application of knowledge-based resources to the marketing of their outputs in several countries. Similarly, Pinho (2007) found that innovation was a determinant of equity-based modes of international market entry.

Kazem and Van der Heijden (2006) argued that firms maintained a competitive level of efficiency and innovation. This leads us to question whether a specific focus on innovation is a more reliable determinant of SME engagement with international market entry than a focus on growth, as implied by traditional stage models. Several internationalization stage models have been proposed, including: the Uppsala process model (Johanson and Vahlne, 1990); the innovation-adoption model (Andersen, 1993); and the management decisionmaking process model (Reid, 1981). Barnes et al (2006) suggested that it was not the type of stage model in born-globals that made them distinct, but rather the ability to learn quickly, resulting in rapid expansion to different markets. Such decision making has implications in explaining reduced time taken from establishment to first export activity (Wright $e t a l$, 2007).

The born-global trend was enabled by globalization processes, the Internet and other trends (Knight et al, 2004). Knight et al (2004, p 646) define born-globals as 'firms less than 20 years old that internationalised on average within three years of founding and generate at least 25 per cent of total sales from abroad'. They state that most born-globals are SMEs, associating firm size with age. Moen (2002), in contrast, found that firm age was of less relevance to understanding differences in a firm than whether or not their operations were global or local in focus.

Rather than categorizing firms by age, Leonidou and Kaleka (1998) identified different stages of exporting, namely experimental, transitional and advanced, and found that experimental exporters used indirect exporting methods, suggesting the usefulness of the continued exploration into stage models. Axinn and Matthyssens (2002) identified psychic distance as an issue relating to the continued relevance of stage models of internationalization. Despite a belief that firms would be likely to expand into markets with high cultural proximity, Stöttinger and Schlegelmilch (1998) disagreed, suggesting that market globalization had outdated the concept of psychic distance. Loane and Bell (2006) identified that rapidly internationalizing SMEs increasingly perceived a global marketplace. Thus owner-manager, firm and environmental factors may be of importance in explaining exporting behaviour, posing issues for SMEs that may remain without export involvement.

\section{Methodology}

Thus the evidence is inconclusive with regard to the variables of importance in determining SME exporting. This is complicated by the phenomenon of born-globals and the consequent potential for different reasons explaining firms of different ages exporting, in addition to the relationship between exporting and firm performance measures. This study is directed at addressing lacunae in the study of the relationship between exporting and SME characteristics, both generally and between different age ranges, contributing to the literature, and consequently understanding of these interrelated issues. The literature suggests that exporting can be explained by firm and owner-manager characteristics and by firm resources, both internally and through networks. Second, these relationships may be affected by firm age. The study offers the following research topics for investigation:

(1) whether exporting SMEs differ from non-exporters in terms of: (a) firm characteristics (sector, size, age, status, growth focus); (b) owner-manager's specific characteristics (age, experience); and (c) resources, including owner-manager-specific resources (education), firm-held resources (IP) and technology (Internet usage), and external network resources (advice on accessing new markets and finance);

(2) whether basic firm factors differ in importance depending on firm age; and

(3) whether there are commonalities across firm ages in terms of the relationships between exporting and resources.

To evaluate these questions, data from the UK's Federation of Small Businesses (FSB) survey (2008) are analysed via a binary logistic multiple regression approach. This method is appropriate for a large dataset 
and complex multifaceted phenomena. Previous research using the FSB data includes Pickernell et al (2010) and Jones et al (2013). Individual SMEs were the unit of analysis, with owner-managers as the key respondents. The survey was sent to the FSB's entire UK membership, and 4,838 usable responses were received.

To examine the research questions, a two-stage approach was undertaken. To answer the first two questions, the whole sample was employed, including an independent variable for firm age $(<4$ years old, $4-9$, $10-19,>20)$. To examine differences and similarities for firms of different ages (comparing young and older firms' groupings), the sample was split by firm age and the regression equation repeated (minus the variable for firm age). The dependent variable employed was twocategory (do not export, export), a binary logistic multiple regression approach was utilized, and separate binomial (logit) regression equations were generated for the sample and each age grouping.

This allowed the relationship between exporting and each individual independent variable to be determined whilst keeping all other independent variables in the equation constant. Tests for robustness of the overall equations were conducted, specifically the omnibus model-fit test, the Hosmer-Lemeshow test (whether or not the respondent was a supplier to that public sector organization) and the variance inflation factor test to ensure no problems with multicollinearity.

For these equations, variables were taken from the dataset or derived by amalgamating categories to generate independent variables (Table 1). The variables were classified under the headings of 'control' variables related to research questions one and three, and 'resource' variables related to research questions two and four. The 'control'-type variables were constructed for a range of factors which represented drivers/barriers to SME exporting. This included several variables highlighted by SME studies (Chrisman et al, 2005). These included industry type, measured using five dummy (yes/no) variables for primary and energy, construction, manufacturing basic and lifestyle services, and highknowledge services, though in the final analysis the primary and energy variable was dropped to avoid overspecification. Firm status was controlled for by constructing a dummy variable for whether or not the firm was a limited company. Firm size was measured by turnover in the previous year in five categories ( $>$ $£ 50,000, £ 50,001-£ 100,000, £ 100,001-£ 300,000$, $£ 300,001-£ 500,000,>£ 500,000$ ).

Data were gathered on firm turnover, growth rate in the previous year and growth aspirations for the following two years, allowing the creation of variables in line with the BERR (2008) definitions of growth orientation and aspirations, namely: sustained growth (by $5 \%+$ in the previous year and intent to grow in the next two years); new growth (by $<5 \%$ in previous year but intending to grow in the next two years); constrained growth (by $>5 \%$ in previous year but not intending to grow in the next two years); no growth (by $<5 \%$ in previous year and not intending to grow in the next two years).

To examine the issue of firms with high growth intention, the sustained growth category was split into high growth intention (by $20 \%+$ in previous year and intending to grow by $20 \%+$ per annum in the next two years) and non-high sustainable growth. Owner-managers' age was measured in three categories $(<45,45-54$, $54+$ ). The firm age groupings (included as a dependent variable in the sample regression and used to categorize firms for the second set of regressions) were $<4,4-9$, $10-19$ and $20+$.

In terms of the acquired resource variables, these were constructed as follows. The FSB (2008) study collected details on qualification levels held. Graduate entrepreneurs were defined as those holding a doctorate, Master's or Bachelor's degree, and non-graduate entrepreneurs as those with professional, A-level, GCSE/O-level, vocational or no formal qualifications. Innovation was measured in terms of patents (Hughes, 2001), design (Hoffman et al, 1998), copyright or trademarks (Kitching and Blackburn, 1998). A binomial variable was constructed on whether the firm had $(>1)$ patent, copyright, trademark or design IP (coded yes/ no).

A variable measuring SMEs' website use (in four categories, from no website, contact details, advertising and advertising plus buying/selling/both) was derived and included in the final analysis, this being split into categorical variables. Firms were asked whether they had received beneficial advice that assisted them to find new markets from customers/suppliers, government business support/trade associations/informal networks. From this, three beneficial advice variables were generated (one for each source), coded as 0 (no beneficial assistance had been derived) and 1 (beneficial assistance had been gained). For finance, respondents were asked whether they had obtained finance from several sources. This was coded 0 where no finance had been obtained and 1 if it had. The data for these variables are displayed in Table 1.

In Table 1, the sign indicates the direction of the relationship (no sign indicating a positive relationship and a minus indicating a negative one), whilst the figures in parentheses are a (non-standardized) oddsratio indication of strength of the relationship between the dependent and independent variable. Significant variables are highlighted in bold and categorized in 
Table 2.

Table 1. Variables.

\section{Variable}

Promoters/impediments to SME exporting

Construction (N/Y)

Basic services $(N / Y)$

High knowledge (N/Y)

Manufacturing (N/Y)

Primary, agriculture, energy

Ltd company $(\mathrm{Y} / \mathrm{N})$

Firm size (turnover)

Less than $£ 50,000$

$£ 50,000-£ 100,000$

$£ 100,001-£ 300,000$

$£ 300,001-£ 500,000$

$£ 500,001+$

Owner/manager previously owned an SME

Owner/manager previously worked in a multinational

Owner/manager's age

$<45$

45-55

$55+$

Firm age (years)

$<4$

4-9

$10-19$

20+

High growth potential

Non-high but sustained growth potential

New growth potential

Constrained growth potential

No growth

Acquired resource-related factors

Owner/manager has degree+

Firm IP (patent, trademark, copyright/design) $(\mathrm{Y} / \mathrm{N})$

Website use

No website

Website for basic contact information

Website for advertising

Website for advertising/selling/buying/both

Received advice to find new markets from customers/suppliers

Received advice to find new markets from government business services

Received advice to find new markets from trade associations and informal networks
Variable description

$\begin{array}{rr}\text { Yes: } & 11.4 \% \\ \text { Yes: } & 42.0 \% \\ \text { Yes: } & 32.5 \% \\ \text { Yes: } & 9.9 \% \\ \text { Yes: } & 4.2 \% \\ \text { Yes: } & 50.2 \% \\ & \\ & 26.5 \% \\ 17.9 \% \\ 27.1 \% \\ 9.9 \% \\ 18.6 \% \\ 45.7 \% \\ 34.9 \%\end{array}$

$25.6 \%$

$32.6 \%$

$41.8 \%$

$19.9 \%$

$29.6 \%$

$27.4 \%$

$23.1 \%$

$7.0 \%$

$28.5 \%$

$25.2 \%$

$12.0 \%$

$27.3 \%$

$29.6 \%$

Yes: $21.1 \%$

$27.7 \%$

$19.1 \%$

$35.7 \%$

$17.5 \%$

Yes: $15.4 \%$

Yes: $\quad 3.2 \%$

Yes: $13.7 \%$
Finance from bank sources used to finance business in previous 2 years (major/minor source)

Yes:

$58.1 \%$

\section{Discussion}

SMEs that exported differed from non-exporters in terms of basic firm characteristics, including sector, size, age and owner-manager-specific characteristics including age and previous experience. Resource relationships were identified in terms of owner-manager-specific resources (education level), firm-held resources (IP and technology (Internet usage)) and external network resources (beneficial advice on finding markets and bank finance). Further, basic factors differed in impor- tance depending on firm age; and there were indeed commonalities to be found across firm ages in terms of relationships between exporting and resources, ownermanager education, Internet use and IP, though not for advice or finance.

Previously, Moen (2002) has posited that newly established global firms have similar characteristics to older global firms, and that newly established firms that retained a local focus had similar characteristics to older, locally focused firms. Our study supports this with regard to resource use, but not in relation to firm characteristics, where exporting was found to be less likely for firms in the construction industry and for firms of all ages except in the youngest category. In contrast, young firms are more likely to export if operating in basic services. 


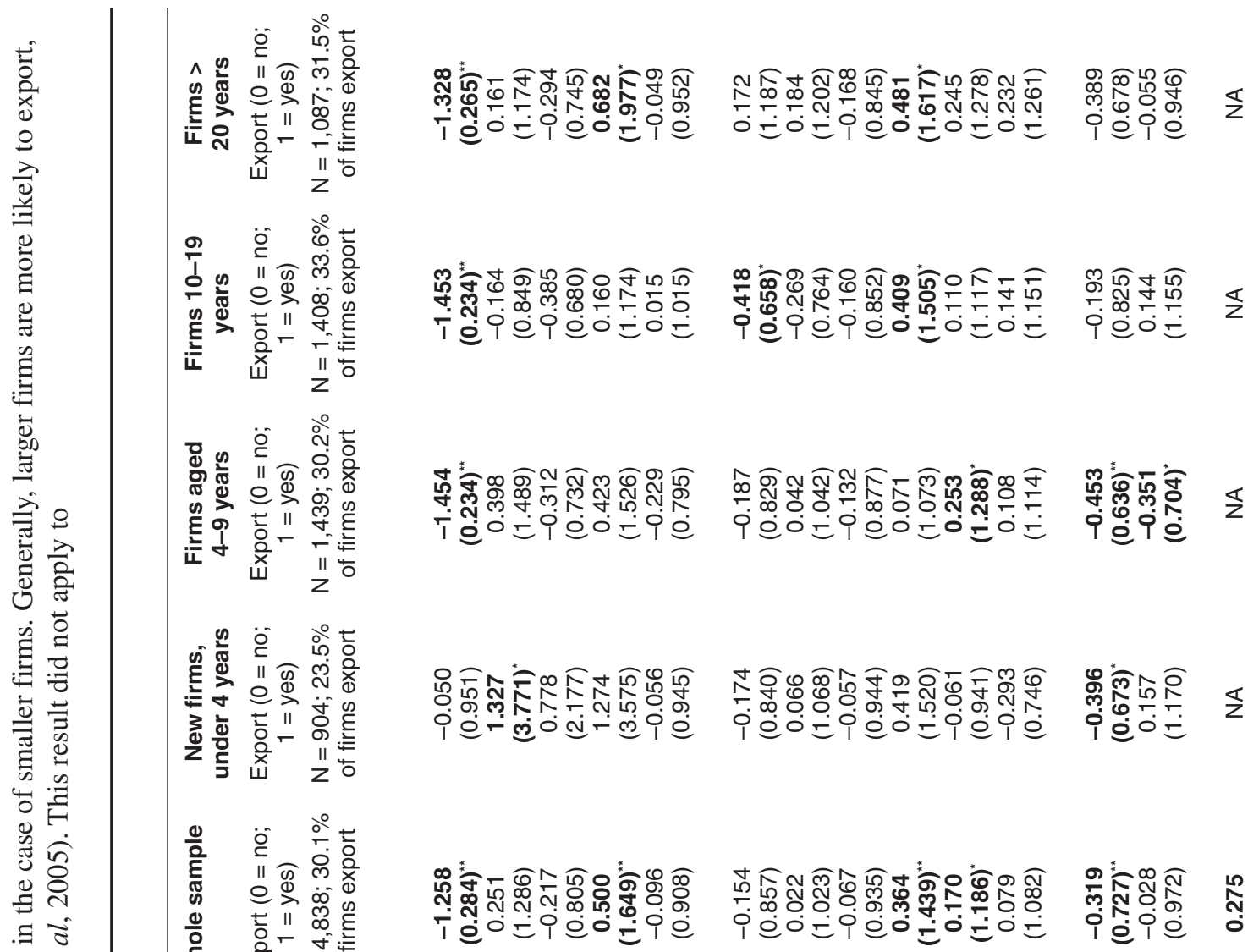




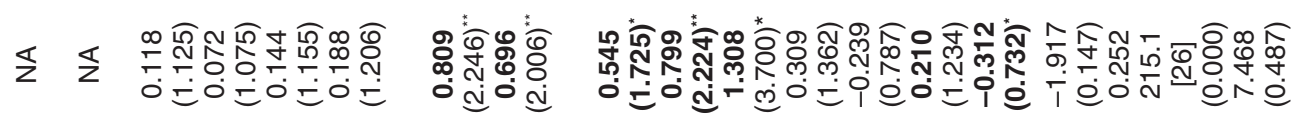

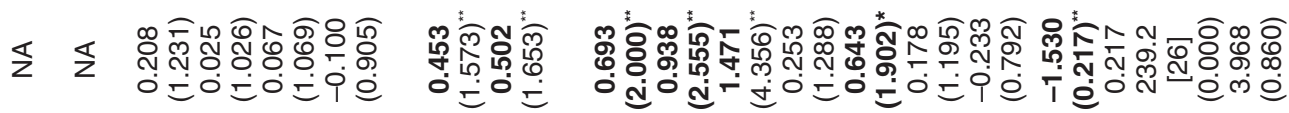

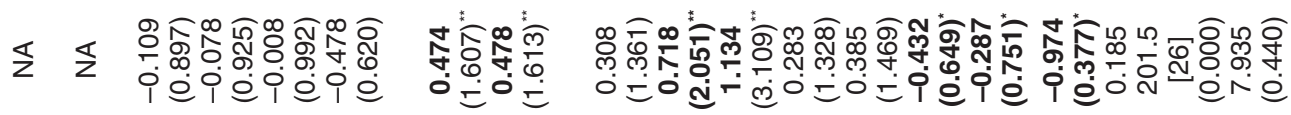

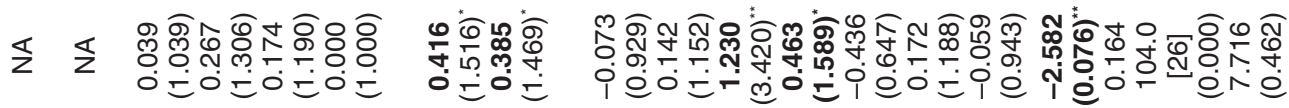

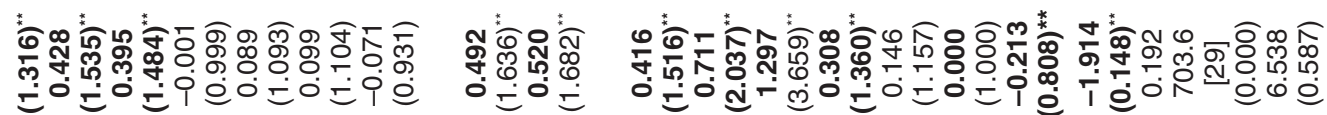
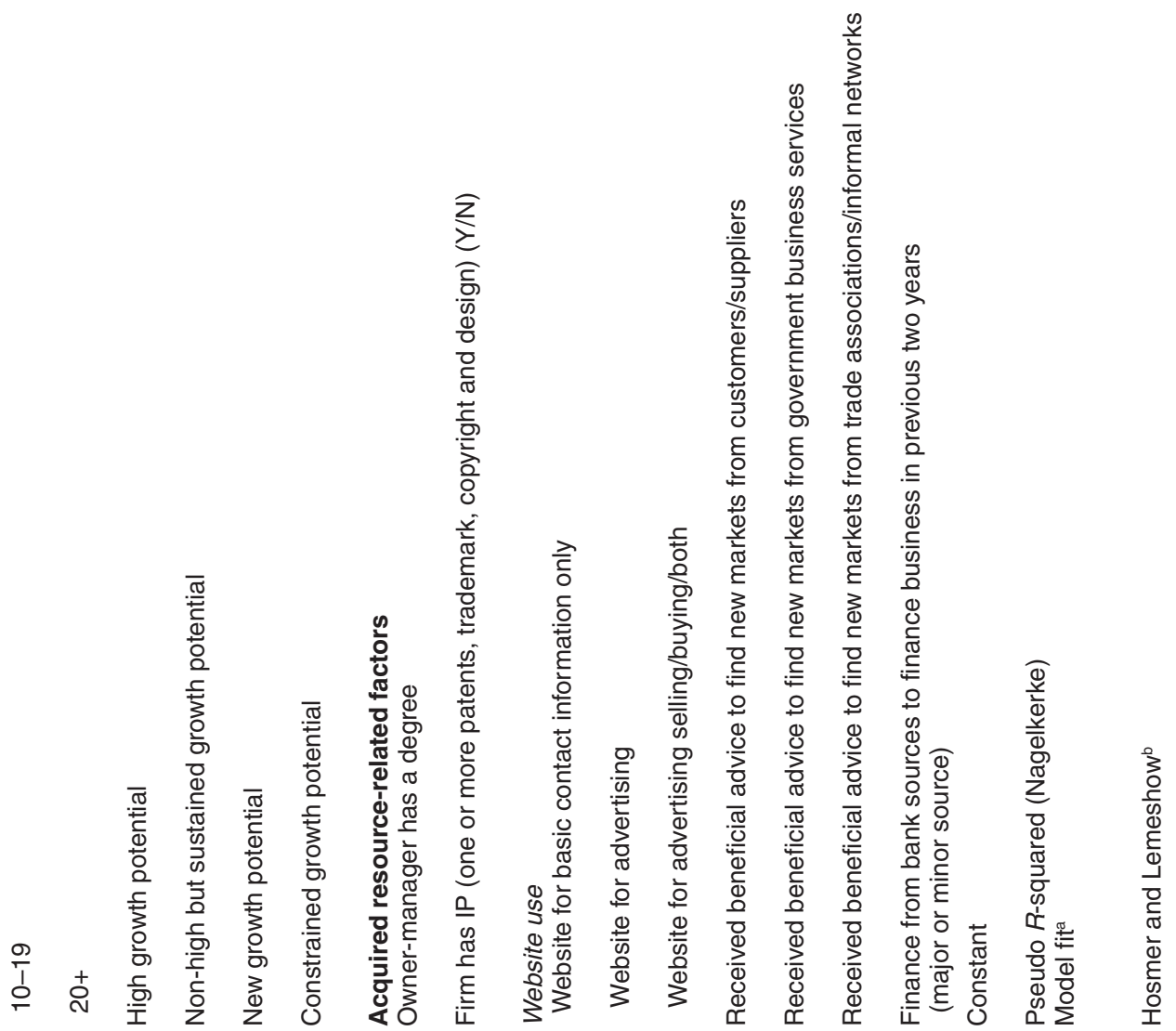
Percentage correct predictions

72.9

77

72.3

71.7

74.2

Note: odds ratios included in parentheses; ${ }^{*} p$-value significant at 0.10 level; ${ }^{*}$ p-value significant at 0.05 level; ${ }^{a}$ chi-square test, degrees of freedom in square brackets, $p$-value in parentheses;

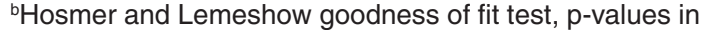
parentheses.

the youngest firms, or those younger than 10 years. Ibeh (2000), considering the decision maker as a determinant of exporting, found that previous international exposure or experience was important. Our results demonstrate that owner-managers with prior management experience are more likely to export, but this is only really seen as a driver for firms aged between four and nine years. While risk is considered as a barrier to engaging in export activity (Kaleka and Katsikeas, 1995), it could be surmised that younger owner-managers may tend to be less risk-averse than older firms. In contrast, the study found that, in general, owner-managers aged under 45 were less likely to export.

Enterprises less than 10 years old are less likely to export, which suggests that the determinant is one of experience and firm age rather than owner-manager's age, as we found that older firms were more likely to export. This contrasts with Knight et al (2004), who claimed that most born-global firms were SMEs, partly as a result of their young age, and other authors who have similarly linked firm age with a propensity to start up as an international enterprise.

In terms of resources there was more commonality. Owner-managers possessing a degree or higher degree were linked to exporting within every SME age group, suggesting that development of an $\mathrm{HC}$ dimension is possible, or that HE influences export-oriented SME owner-managers. Possessing IP is positively linked to exporting, and becomes increasingly important for older firms, so owner-managers should be encouraged via policy makers.

An innovation focus was found to be positively linked to exporting; however, a growth focus was not, supporting the literature. But this study did not consider any subtle differences in these data based on different stages of exporting, which warrants future research (Leonidou and Kaleka, 1998). Extensive website use is also positively related to exporting, and the effect is seen at lower levels of Internet usage for older firms. This suggests a differential policy approach (for young firms to develop skills for effective Internet use, and for older firms to be encouraged to increase deployment).

$\mathrm{Au}$ and Ho (2002) claim that it is imperative for government export promotion policy to be aligned to support SME technology usage. While this study is not focused on policy making, it is recognized that this can enable SME exporting performance. Such resources are relatively easy for a nascent exporting entrepreneur to acquire. For other resources, particularly market advice and finance, notable differences were apparent across firm age. Young firms that export are more likely to have received beneficial advice from customers/suppliers that helped them find new markets. Firms aged 4-9 years are less likely to have received advice from trade associations/networks, possibly explained by associations' focus on domestic markets (getting by versus getting ahead).

Firms aged 10-19 years that export are more likely to have had beneficial advice from government. This could be because governments want a track record, or because the type of advice provided is only useful to older firms. Obtaining finance is negatively related to exporting, particularly for firms more than 20 years old. This may be because a firm seeking finance is less likely to have the resources to export, indicating resource weakness rather than strength, which requires further research.

\section{Conclusions}

This research explored determinants of SME exporting based on an analysis of firm characteristics and their resources. The findings indicate that SMEs that export differ in their characteristics relative to non-exporters and across firm age boundaries. In terms of resources, a consistently positive and significant linkage was identified across variables: for example, between degree-level (or higher) education and an export orientation. This suggests that graduates play an important role in enhancing SMEs' export performance.

This is novel evidence that could be used by policy makers regarding the value of graduate-level-trained owner-managers to firm exporting behaviour. This evidence could be presented to graduates and universities to encourage entrepreneurial career options. SMEs with IP were positively linked to exporting behaviour, the relationship growing stronger for older firms. Thus policy makers could encourage SMEs to obtain IP not only for its own sake, but as a way to link to potential exporting behaviour.

Similarly, the effective use of website technology (associated with e-commerce trading to enhance the business) was linked to exporting behaviour. SMEs must be encouraged by policy makers to utilize sophisticated technology effectively. There were differences in advice sources - associated with firm age - and their impact on exporting behaviour. Policy makers should consider the effectiveness and impact of promoting sources of business advice to firms of different ages as a means of 
encouraging exporting behaviour. SMEs claiming a growth focus were a phenomenon not related to export orientation, suggesting a need for further research.

Study limitations included the need to explore further the results related to financing. Furthermore, the study was only able to examine differences between firms that exported and those that did not, rather than examining the degree of export activity (percentage of total turnover). Additional research examining this would be useful in analysing the impact of some of the variables in this study, including qualifications, IP and business advice.

\section{References}

Abor, J., and Biekpe, N. (2006), 'How are SMEs financed? Evidence from the Ghanaian nontraditional export sector', Environment and Planning C: Government and Policy, Vol 24, No 1, pp 71-81.

Andersen, O. (1993), 'On the internationalization process of firms: a critical analysis', Journal of International Business Studies, Vol 24, No 4, pp 728-755.

Andersson, S., Gabrielsson, J., and Wictor, I. (2004), 'International activities in small firms: examining factors influencing the internationalization and export growth of small firms', Canadian Journal of Administrative Sciences, Vol 21, No 1, pp 22-34.

Arteaga-Ortiz, J., and Fernández-Ortiz, R. (2010), 'Why don’t we use the same export barrier measurement scale? An empirical analysis in small and medium-sized enterprises', Journal of Small Business Management, Vol 48, No 3, pp 395-420.

$\mathrm{Au}$, K.F., and Ho, D.C.K. (2002), 'Electronic commerce: a business model for Hong Kong clothing SMEs', International Journal of Services Technology and Management, Vol 3, No 1, pp 5-21.

Axinn, C.N., and Matthyssens, P. (2002), 'Limits of internationalization theories in an unlimited world', International Marketing Review, Vol 19, No 5, pp 436-449.

Balabanis, G., Theodosiou, M., and Katsikea, E.S. (2004), 'Guest Editorial: Export marketing: developments and a research agenda', International Marketing Review, Vol 21, No 4/5, pp 353-377.

Barnes, B., Chakrabarti, R., and Palihawadana, D. (2006), 'Investigating the export marketing activity of SMEs operating in international healthcare markets', Journal of Medical Marketing, Vol 6, No 3, pp 209-221.

Beck, T., and Demirguc-Kunt, A. (2006), 'Small and medium-size enterprises: access to finance as a growth constraint', Journal of Banking \& Finance, Vol 30, No 11, pp 2931-2943.

Bell, J. (1997), 'A comparative study of the export problems of small software exporters in Finland, Ireland and Norway', International Business Review, Vol 6, No 6, pp 585-604.

Bell, J., and Young, S. (1998), 'Towards an integrative framework of the internationalisation of the firm', in Hooley, G., Loveridge, R., and Wilson, D., eds, Internationalisation: Process, Context and Markets, Macmillan, London.

BERR (2008), Annual Small Business Survey, Department for Business, Enterprise and Regulatory Reform, Institute for Employment Studies, London.

Boehe, D. (2013), 'Collaborate at home to win abroad: how does access to local network resources influence export behavior?' Journal of Small Business Management, Vol 51, No 2, pp 167-182.

Camisón, C., and Villar-López, A. (2010), 'Effect of SMEs' international experience on foreign intensity and economic performance: the mediating role of internationally exploitable assets and competitive strategy', Journal of Small Business Management, Vol 48, No 2, pp 116-151.

Chetty, S., and Blankenburg Holm, D. (2000), 'Internationalisation of small to medium sized manufacturing firms: a network approach', International Business Review, Vol 9, No 1, pp 7793.

Chetty, S., and Campbell-Hunt, C. (2004), 'A strategic approach to internationalization: a traditional versus a "born-global" approach', Journal of International Marketing, Vol 12, No 1, pp 57-81.

Chrisman, J., McMullan, W., and Hall, J. (2005), 'The influence of guided preparation on the long term performance of new ventures', Journal of Business Venturing, Vol 20, No 6, pp 769-791.

Clark, T., and Pugh, D.S. (2001), 'Foreign country priorities in the internationalization process: a measure and an exploratory test on British firms', International Business Review, Vol 10, No 3, pp 285-303.

Crick, D. (2009), 'The internationalisation of born global and international new venture SMEs', International Marketing Review, Vol 26, No 4/5, pp 453-476.

Crick, D., and Chaudhry, S. (2006), 'International marketing strategy in the electronics industry: a follow-up investigation of UK SMEs 18 months after the export withdrawal decision', Journal of Strategic Marketing, Vol 14, No 3, pp 277-292.

Crick, D., and Spence, M. (2005), 'The internationalisation of "high performing" UK high-tech SMEs: a study of planned and unplanned strategies', International Business Review, Vol 14, No 2, pp 167-185.

Di Chiara, A., and Minguzzi, A. (2002), 'Success factors in SMEs' internationalization processes: an Italian investigation', Journal of Small Business Management, Vol 40, No 2, pp 144-153.

Fletcher, D. (2004), 'International entrepreneurship and the small business', Entrepreneurship and Regional Development, Vol 16, No 4, pp 289-305.

Fliess, B., and Busquets, C. (2006), 'The role of trade barriers in SME internationalisation', OECD Papers, Vol 6, No 13, pp 119.

Frackiewicz, E., and Grzesiuk, A. (2013), 'Model of the SME's internationalization through e-commerce. Preliminary verification and development of the model', International Journal of Management Cases, Vol 15, No 2, pp 59-76.

FSB (2008), Lifting the Barriers to Growth in UK Small Businesses, Federation of Small Businesses, London.

Gabrielsson, J., Lindholm Dahlstrand, Å., and Politis, D. (2014), 'Sustainable high-growth entrepreneurship: a study of rapidly growing firms in the Scania region', International Journal of Entrepreneurship and Innovation, Vol 15, No 1, pp 29-40.

Gassmann, O., and Keupp, M. (2007), 'The competitive advantage of early and rapidly internationalising SMEs in the biotechnology industry: a knowledge-based view', Journal of World Business, Vol 42, No 3, pp 350-366.

Greenaway, D., Guariglia, A., and Kneller, R. (2007), 'Financial factors and exporting decisions', Journal of International Economics, Vol 73, No 2, pp 377-395.

Hamill, J., and Gregory, K. (1997), 'Internet marketing in the internationalisation of UK SMEs', Journal of Marketing Management, Vol 13, No 1/3, pp 9-28.

Hart, S., and Tzokas, N. (1999), 'The impact of marketing research activity on SME export performance: evidence from the UK', Journal of Small Business Management, Vol 37, No 2, pp 63-75.

Hessels, J., and Terjesen, S. (2008), 'Entrepreneurial career capital, innovation and new venture export orientation', Scientific Analysis of Entrepreneurship and SMEs, SMEs and Entrepreneurship Programme financed by the Netherlands Ministry of Economic Affairs, The Hague.

Hinson, R., and Abor, J. (2005), 'Internationalizing SME non- 
traditional exporters and their Internet use idiosyncrasies', Perspectives on Global Development \& Technology, Vol 4, No 2, pp 229-244.

Hoffman, K., Milady, P., Bessant, J., and Perren, L. (1998), 'Small firms, $R \& D$, technology, and innovation in the UK: a literature review', Technovation, Vol 18, No 1, pp 39-55.

Holzmuller, H.H., and Stottinger, B. (1996), 'Structural modelling of success factors in exporting: cross-validation and further development of an export performance model', Journal of International Marketing, Vol 4, No 2, pp 29-55.

Hughes, A. (2001), 'Innovation and business performance: small entrepreneurial firms in the UK', in Economic Growth and Government Policy, HM Treasury, London, pp 65-70.

Ibeh, K. (2000), 'Internationalisation and the small firm', in Jones-Evans, D., and Carter, S, eds, Enterprise and Small Business: Principles, Practice and Policy, Prentice-Hall, London, pp 434-452.

Johanson, J., and Vahlne, J.E. (1990), 'The mechanism of internationalisation', International Marketing Review, Vol 7, No 4, pp 11-24.

Jones, P., Beynon, M.J., Pickernell, D., and Packham, G. (2013), 'Evaluating the impact of different training methods on SME business performance', Environment and Planning $C$ : Government and Policy, Vol 31, No 1, pp 56-81.

Jones, P., Scherle, J., Pickernell, D., Packham, G., Skinner, H., and Peisl, T. (2014), 'Fool's gold: the value of business awards to small businesses', International Journal of Entrepreneurship and Innovation, Vol 15, No 2, pp 89-100.

Kaleka, A., and Katsikeas, C. (1995), 'Exporting problems: the relevance of export development', Journal of Marketing Management, Vol 5, No 3, pp 499-515.

Kazem, A., and Van der Heijden, B. (2006), 'Exporting firms' strategic choices: the case of Egyptian SMEs in the food industry', SAM Advanced Management Journal, Vol 71, No 3, pp 21-33.

Kitching, J., and Blackburn, R. (1998), 'Intellectual property management in the small and medium enterprise (SME)', Journal of Small Business and Enterprise Development, Vol 5, No 4, pp 327-335.

Knight, G., Madsen, T.K., and Servais, P. (2004), 'An inquiry into born-global firms in Europe and the USA', International Marketing Review, Vol 23, No 5, pp 645-665.

Kocak, A., and Abimbola, T. (2009), 'The effects of entrepreneurial marketing on born global performance', International Marketing Review, Vol 26, No 4/5, pp 439-452.

Kontinen, T., and Ojala, A. (2010), 'International opportunity recognition among small and medium-sized family firms', Journal of Small Business Management, Vol 49, No 3, pp 490-514.

Leonidou, L. (2004), 'An analysis of the barriers hindering small business export development', Journal of Small Business Management, Vol 42, No 3, pp 279-302.

Leonidou, L.C., and Kaleka, A.A. (1998), 'Behavioural aspects of international buyer-seller relationships: their association with export involvement', International Marketing Review, Vol 15, No 5, pp 373-397.

Loane, S., and Bell, J. (2006), 'Rapid internationalisation among entrepreneurial firms in Australia, Canada, Ireland and New Zealand: an extension to the network approach', International Marketing Review, Vol 23, No 5, pp 467-485.

Love, P., Irani, Z., Standing, C., Lin, C., and Burn, J. (2005), 'The enigma of evaluation: benefits, costs and risks of IT in Australian small-medium-sized enterprises', Information and Management, Vol 42, No 7, pp 947-964.

Madsen, K., and Servais, P. (1997), 'The internationalisation of born globals: an evolutionary process', International Business Review, Vol 6, No 6, pp 561-583.

Maskus, K., and Penubarti, M. (1995), 'How trade-related are intellectual property rights?' Journal of International Economics, Vol 39, No 3/4, pp 227-248.

Massey, C. (2006), 'A new conceptualisation of business development for SMEs: a focus on development potential', Environment and Planning C: Government and Policy, Vol 23, No 4, pp 37-49.

Merrilees, B., and Tiessen, J. (1999), 'Building generalizable SME international marketing models using case studies', International Marketing Review, Vol 16, No 4/5, pp 326-344.

Miocevic, D., and Crnjak-Karanovic, B. (2011), 'Cognitive and information-based capabilities in the internationalization of small and medium-sized enterprises: the case of Croatian exporters', Journal of Small Business Management, Vol 49, No 4, pp 537-557.

Mittelstaedt, J., Harben, G., and Ward, W. (2003), 'How small is too small? Firm size as a barrier to exporting from the United States', Journal of Small Business Management, Vol 40, No 1, pp 68-84.

Moen, $\varnothing$. (2002), 'The born globals: a new generation of small European exporters', International Marketing Review, Vol 19 , No 2, pp 156-175.

Mole, K., Hart, M., Roper, S., and Saal, D. (2008), 'Differential gains from Business Link support and advice: a treatment effects approach', Environment and Planning C: Government and Policy, Vol 26, No 2, pp 315-334.

Oviatt, B., and McDougall, P. (1994), 'Towards a theory of international new ventures', Journal of International Business Studies, Vol 25, No 1, pp 45-64.

Pellinen, K. (2014), 'The interplay of entrepreneurial and network activities in the entrepreneurial process: a relational analysis', International Journal of Entrepreneurship and Innovation, Vol 15, No 1, pp 17-28.

Pickernell, D., Packham, G., Brooksbank, D., and Jones, P. (2010), 'A recipe for what? UK universities, enterprise and knowledge transfer: evidence from the Federation of Small Businesses 2008 survey', International Journal of Entrepreneurship and Innovation, Vol 11, No 4, pp 265-272.

Pickernell, D., Packham, G., Jones, P., and Miller, C. (2011), 'Graduate entrepreneurs are different: they have more knowledge?' International Journal of Entrepreneurial Behaviour and Research, Vol 17, No 2, pp 183-202.

Pinho, J.C. (2007), 'The impact of ownership: location-specific advantages and managerial characteristics on SME foreign entry mode choices', International Marketing Review, Vol 24, No 6, pp 715-734.

Pope, R. (2002), 'Why small firms export: another look', Journal of Small Business Management, Vol 40, No 1, pp 17-26.

Primo Braga, C., and Fink, C. (2000), 'International transactions in intellectual property and developing countries', International Journal of Technology Management, Vol 19, No 1/2, pp 3556.

Reid, S. (1981), 'The decision-maker and export entry and expansion', Journal of International Business Studies, Vol 12, No 2, pp 101-112.

Robson, P., and Bennett, R. (2000), 'SME growth: the relationship with business advice and external collaboration', Small Business Economics, Vol 15, No 3, pp 193-208.

Smarzynska Javorcik, B. (2004), 'The composition of foreign direct investment and protection of intellectual property rights: evidence from transition economies', European Economic Review, Vol 48, No 1, pp 39-62.

Smith, P.J. (2001), 'How do foreign patent rights affect U.S exports, affiliate sales and licenses?' Journal of International Economics, Vol 55, No 2, pp 411-439.

Stöttinger, B., and Schlegelmilch, B.B. (1998), 'Explaining export development through psychic distance: enlightening or elusive?' International Marketing Review, Vol 15, No 5, pp 357-372.

Westhead, P., Wright, M., and Ucbasaran, D. (2004), 'Internationalisation of private firms: environmental turbulence and organisational strategies and resources', Entrepreneurship and Regional Development, Vol 16, No 6, pp 501-522.

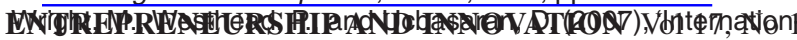
alization of small and medium-sized enterprises (SMEs) and international entrepreneurship: a critique and policy implica- 